\title{
PENINGKATAN KECERDASAN EKOLOGIS PESERTA DIDIK DALAM BERTRANSPORTASI HEMAT BBM MELALUI PEMBELAJARAN IPS KONTEKSTUAL \\ (PTK di Kelas VII A SMP Negeri 2 Tomo Kabupaten Sumedang Pada Materi Kelangkaan Sumber Daya Alam)
}

\author{
Tati Setiawati \\ Guru IPS di SMP Negeri 2 Tomo Kabupaten Sumedang \\ (Mahasiswa Pascasarjana Prodi PIPS UPI) \\ thie.spd@gmail.com
}

\begin{abstract}
ABSTRAK
Penelitian ini berawal dari kecemasan peneliti terhadap kondisi obyektif peserta didik di SMP Negeri 2 Tomo yang menggunakan sepeda motor sebagai alat transportasi ke sekolah. Mereka nampak belum menyadari dampak yang ditimbulkan dari penggunaan sepeda motor terhadap berbagai aspek, baik hukum, ekonomi, sosial, keselamatan dan juga terhadap penurunan kualitas lingkungan akibat konsumsi BBM dan polusi yang dihasilkan dari sisa pembakaran BBM. Selain itu dalam pembelajaran IPS, guru belum mengaitkan materi dengan permasalahan sosial dan lingkungan yang dihadapi peserta didik dalam kehidupan nyata. Oleh karena itu, melalui materi "Kelangkaan sumber daya alam" yang disisipkan dalam Standar Kompetensi 6 "Memahami kegiatan ekonomi masyarakat" silabus IPS Kelas VII semester dua KTSP, peneliti melakukan penelitian tindakan kelas sebagai bentuk perbaikan masalah lingkungan sekolah dan peningkatan kecerdasan ekologis peserta didik dalam bertransportasi hemat BBM melalui Pembelajaran IPS Kontekstual. Desain penelitian tindakan kelas yang digunakan adalah model PTK Elliot. Berdasarkan hasil penelitian tindakan kelas yang dilakukan sebanyak tiga siklus dengan dua belas kali pertemuan, diperoleh peningkatan kompetensi kecerdasan ekologis peserta didik, baik aspek pengetahuan, sikap maupun aspek keterampilan. Data awal pada siklus kesatu menunjukkan nilai kompetensi kecerdasan ekologis berada pada kategori "kurang" dan mengalami peningkatan pada siklus kedua menjadi kategori "cukup", serta menjadi kategori "baik" pada siklus ketiga. Dengan demikian dapat disimpulkan bahwa pembelajaran IPS kontekstual secara efektif meningkatkan kecerdasan ekologis peserta didik dalam bertransportasi hemat BBM di kelas VII A SMP Negeri 2 dan dapat diterapkan di sekolah menengah pertama lainnya yang mempunyai karakteristik daerah serupa.
\end{abstract}

Kata Kunci: Kecerdasan Ekologis, Transportasi Hemat BBM, Pembelajaran IPS Kontekstual.

\section{PENDAHULUAN}

Dewasa ini para pelajar yang menggunakan sepeda motor sebagai moda transportasi ke sekolah menjadi salah satu fenomena di kalangan masyarakat Indonesia. Trend bersepeda motor menjadi gengsi tersendiri dalam pergaulannya. Mereka lebih percaya diri apabila mengendarai sepeda motornya dibandingkan dengan naik angkutan umum, jalan kaki ataupun sepeda yang sudah familier di kalangan masyarakat Indonesia. Perkembangan IPTEK yang sangat pesat dalam jenis transportasi ini seperti bentuk, model, mesin, dan harga sepeda motor yang terjangkau juga semakin beragamnya aktivitas manusia mendorong terhadap meningkatnya penggunaan sepeda motor di masyarakat. 
Selain hal tersebut, penggunaan sepeda motor oleh anak menurut Rahadian (2014), dipengaruhi oleh beberapa faktor, yaitu faktor keluarga, pendidikan/sekolah, dan faktor pergaulan anak. Faktor keluarga berupa dukungan orangtua/keluarga yang sengaja memperbolehkan anak belajar dan mengendarai sepeda motor. Faktor pendidikan dan sekolah, karena kurangnya sosialisasi tentang tertib lalu lintas dan pihak sekolah yang tidak menerapkan tata tertib sekolah dengan konsisten. Sementara itu, faktor pergaulan anak berasal dari teman-temannya yang terlebih dahulu mempunyai dan mengendarai sepeda motor yang telah mendorong mereka untuk memiliki barang yang sama dengan temannya.

Kondisi ini sangat memprihatinkan, apalagi terdapat dukungan orang tua didalamnya. Orangtua memberikan ijin mengendarai sepeda motor kepada anaknya dengan alasan menggunakan sepeda motor dapat lebih cepat sampai sekolah, bisa menghemat waktu, dan lebih ekonomis (Apandi, 2015). Kondisi transportasi umum yang kurang aman dan nyaman juga sering dijadikan alasan mengapa mereka lebih senang membawa sepeda motor ke sekolah daripada naik kendaraan umum.

Apabila ditinjau dari efektifitas waktu, penggunaan sepeda motor dapat mempercepat para pelajar sampai ke sekolah, akan tetapi sebenarnya dampak negatifnya jauh lebih banyak daripada itu. Perilaku para pelajar yang sering melanggar undang-undang lalu lintas seperti tidak memiliki SIM, tidak menggunakan helm, menggunakan knalpot bising, ugal-ugalan di jalan raya dan semakin maraknya genk-genk motor dapat membahayakan keselamatan dirinya juga membahayakan orang lain. Akibatnya, angka kecelakaan lalu lintas yang melibatkan para pelajar cukup tinggi. Berdasarkan data dari Kapolri (2013) dalam Apandi (2015), angka kecelakaan akibat kecelakaan lalu lintas semakin hari semakin memprihatinkan, jika dirata-ratakan 244 kasus kecelakaan setiap hari dan 20\% diantaranya melibatkan remaja berusia dibawah 16 tahun dengan status pelajar.

Fenomena para pelajar yang menggunakan sepeda motor ke sekolah dan akibat yang menyertainya nampak terjadi juga di SMP Negeri 2 Tomo Kabupaten Sumedang, tempat peneliti mengajar. Berdasarkan data hasil observasi awal penelitian ditemukan bahwa banyak peserta didik lebih memilih untuk menggunakan sepeda motor ke sekolah daripada berjalan kaki ataupun bersepeda, padahal jika dilihat dari jarak tempat tinggal ke sekolah yang cukup dekat $( \pm 1-2,5 \mathrm{Km})$ dan topografi daerahnya yang rata sangat memungkinkan untuk berjalan kaki ataupun bersepeda ke sekolah. Sebagian besar peserta didik memiliki sepeda di rumahnya, tetapi tidak digunakan dengan berbagai alasan. Tingkat penggunaan sepeda motor di kelas VII A lebih tinggi bila dibandingkan dengan kelas VII lainnya. Peserta didik nampak belum memahami kaitan antara penggunaan sepeda motor terhadap penurunan kualitas lingkungannya, baik terhadap ketersediaan BBM, pencemaran udara maupun pemanasan global.

Berdasarkan pemaparan di atas, peneliti dapat menyimpulkan bahwa kesadaran peserta didik dalam bertransportasi hemat BBM yang ramah lingkungan diduga masih kurang atau dengan kata lain kecerdasan ekologis peserta didik masih rendah. Kecerdasan ekologis, menurut Supriatna (2016, hlm. 24) didasari pengetahuan, kesadaran, dan keterampilan hidup selaras dengan alam. Seseorang yang memiliki kecerdasan ekologis akan memahami setiap perilaku dan tindakannya tidak hanya berdampak pada dirinya dan orang lain, akan tetapi berdampak juga terhadap lingkungan alam tempat dia tinggal yang harus dijaga agar tetap memiliki 
daya dukung bagi kehidupan dirinya dan orang lain. Kecerdasan ekologis ini dapat dibina dan dikembangkan melalui pembelajaran IPS.

Di sisi lain, masalah penggunaan sepeda motor oleh para pelajar di SMP Negeri 2 Tomo dan dampak yang dapat ditimbulkannya belum digunakan sebagai sumber dan media pembelajaran IPS. Padahal masalah tersebut merupakan masalah riil yang dihadapi sekolah dan peserta didik yang menuntut adanya solusi praktis sebagai upaya untuk mengatasinya. Pembelajaran yang mengaitkan materi yang dipelajari dengan kondisi nyata peserta didik sehari-hari, baik dalam lingkungan keluarga, sekolah, masyarakat ataupun warga negara dan berusaha mendorong peserta didik untuk menerapkannya dalam kehidupan sehari-hari disebut pembelajaran Kontekstual (Komalasari, 2014, hlm. 7).

Berkaitan dengan kondisi pemahaman materi ajar oleh peserta didik, Depdiknas (2013) memberikan gambaran umum kondisi proses kegiatan belajar mengajar yang selama ini berlangsung di sekolah dan dinilai sangat mengecewakan sebagai berikut:

1. Banyak siswa mampu menyajikan tingkat hapalan yang baik terhadap materi ajar yang diterimanya, tetapi pada kenyataannya mereka tidak memahaminya.

2. Sebagian besar dari siswa tidak mampu menghubungkan antara apa yang mereka pelajari dengan bagaimana pengetahuan tersebut akan dipergunakan/dimanfaatkan.

3. Siswa memiliki kesulitan untuk memahami konsep akademik sebagaimana mereka biasa diajarkan yaitu dengan menggunakan sesuatu yang abstrak dan metode ceramah.

Peneliti berasumsi dengan menggunakan model pembelajaran kontekstual dapat membangun dan menumbuhkan kecerdasan ekologis peserta didik dalam bertransportasi hemat BBM, bukan dari aspek kognitif saja tetapi lebih kepada tindakan riil dalam kehidupan sehari-hari. Materi yang disampaikan akan lebih bermakna karena menggunakan masalah nyata yang dekat dengan kehidupan peserta didik sebagai sumber dan media pembelajaran. Upaya guru dalam meningkatkan kompetensi kecerdasan ekologis peserta didik dalam pembelajaran dimulai dengan menyusun dan mengintegrasikan indikator-indikator kecerdasan ekologis ke dalam SK dan KD yang terkandung dalam KTSP dengan materi kelangkaan sumber daya alam. Diharapkan melalui isu kelangkaan sumber daya alam (BBM) dan kerusakan lingkungan yang diakibatkan oleh konsumsi BBM, peserta didik akan memiliki kesadaran untuk lebih mencintai lingkungannya dengan menjadi green consumer dan green behavior yang pada akhirnya dapat direalisasikan dalam kehidupan sehari-hari, yaitu bersepeda.

Berdasarkan pemaparan di atas, penulis merasa tertarik untuk mengadakan penelitian dengan judul "Peningkatan Kecerdasan Ekologis Peserta didik dalam Bertransportasi Hemat BBM melalui Pembelajaran IPS Kontekstual" dalam sebuah penelitian tindakan kelas yang akan dilakukan di Kelas VII A SMP Negeri 2 Tomo Kabupaten Sumedang pada materi Kelangkaaan Sumber Daya Alam.

\section{RUMUSAN MASALAH}

Berdasarkan latar belakang penelitian yang telah dipaparkan di atas, maka rumusan masalah dalam penelitian ini adalah sebagai berikut:

1. Bagaimana pendidik mendesain pembelajaran IPS Kontekstual untuk meningkatkan kecerdasan ekologis peserta didik dalam bertransportasi hemat 
BBM di kelas VII A SMP Negeri 2 Tomo pada materi Kelangkaan Sumber Daya Alam?

2. Bagaimana pendidik mengimplementasikan pembelajaran IPS Kontekstual untuk meningkatkan kecerdasan ekologis peserta didik dalam bertransportasi hemat BBM di Kelas VII A SMP Negeri 2 Tomo Kabupaten Sumedang pada materi Kelangkaan Sumber Daya Alam?

3. Bagaimana pendidik merefleksikan pembelajaran IPS Kontekstual untuk meningkatkan kecerdasan ekologis peserta didik dalam bertransportasi hemat BBM di kelas VII A SMP Negeri 2 Tomo Kabupaten Sumedang pada materi Kelangkaan Sumber Daya Alam?

4. Bagaimana peningkatan kecerdasan ekologis peserta didik dalam bertransportasi hemat BBM melalui Pembelajaran IPS Kontekstual di kelas VII A SMP Negeri 2 Tomo Kabupaten Sumedang pada materi Kelangkaan Sumber Daya Alam?

\section{KAJIAN PUSTAKA}

\section{A. Kecerdasan Ekologis}

Goleman (2010, hlm. 38) mengemukakan bahwa kecerdasan ekologis sebagai kemampuan manusia beradaptasi dalam ceruk ekologi tempat manusia berada. Kecerdasan ekologis merupakan sebuah kemampuan atau kompetensi yang dimiliki peserta didik dalam merespon keadaan yang terjadi di sekitar lingkungannya dan mengaplikasikannya dalam kehidupannya sehari-hari. Adapun Gardner (2013, hlm. 34) menyebut kecerdasan ekologis dengan istilah kecerdasan naturalis. Menurutnya, kecerdasan naturalis merupakan kemampuan manusia dalam memahami gejalagejala alam, memperlihatkan kesadaran ekologis dan menunjukkan kepekaan terhadap bentuk-bentuk alam.

Selaras dengan pendapat di atas, Orr (dalam Ardiansyah, 2015, hlm. 11) mengemukakan tentang gambaran seseorang yang memiliki kecerdasan ekologis dicirikan dengan 'The ecoligically literate person has the knowledge necessary to comprehend interrelatedness, and attitude of care or stewardship. Such a person would also have the parctical competence required to act on the basis of kowledge and feeling'. Maksud pernyataan Orr tersebut adalah seseorang yang cerdas secara ekologis memiliki pengetahuan tentang pentingnya memahami keterkaitan atau interrelasi antara satu kelompok dengan komponen lainnya serta bersikap peduli terhadap sebuah pekerjaan. Artinya seseorang yang melek ekologi tahu cara berhubungan dan bersikap dengan ekosistemnya.

Supriatna (2016, hlm. 87-88) mengemukakan bahwa kecerdasan ekologis sangat penting dikembangkan dalam proses pembelajaran karena para lulusan sekolah akan berperan sebagai: 1) agent of change di masyarakat, yaitu agen dalam mengembangkan perilaku masyarakat yang memiliki pengetahuan, wawasan, sikap dan perilaku yang menjunjung tinggi kesinambungan atau keberlanjutan (sustainability), 2) agen yang sadar dengan keterbatasan sumber daya alam dan adanya isu global warming dan 3) agen yang bisa menerapkan kecerdasan ekologis atau aplikasi pembelajaran yang bersifat ekopedagosis dalam kehidupan.

Keberlangsungan kehidupan manusia pada masa yang akan datang akan tergantung pada kecerdasan ekologis. Agar peserta didik memiliki kecerdasan ekologis, maka diperlukan sebuah kompetensi yang menjadi indikator tercapainya penanaman pemahaman kecerdasan ekologis pada peserta didik. Palmer \& Neal (1994, hlm. 21-27) menjelaskan bahwa kompetensi ekologis dalam dunia pendidikan 
dapat dicapai dengan mengembangkan kepekaan, kesadaran, pemahaman, pemikiran kritis, dan memecahkan masalah yang berhubungan dengan permasalahan lingkungan hidup serta pembentukan etika lingkungan. Mendukung hal tersebut, pusat ekoliterasi (Center for Ecoliteracy) tersedia dalam (http://www.ecoliteracy.org/publications/fritjop) telah mengembangkan satu set "kompetensi inti" untuk membantu generasi muda mengembangkan dan hidup dalam masyarakat yang berkelanjutan. Kompetensi ini berhubungan dengan pengetahuan (learning to know), sikap (learning to be), tindakan (learning to do) dan hubungan dengan manusia dan alam sekitar (learning to live together). Kompetensi itu antara lain mencakup:

Tabel 1 Kompetensi Kecerdasan Ekologis dari Centre for Ecoliteracy

\begin{tabular}{|c|c|c|}
\hline $\begin{array}{l}\text { Kompetensi inti } \\
\text { dari Centre for } \\
\text { Ecoliteracy }\end{array}$ & $\begin{array}{l}\text { Subkompetensi dari kompetinsi } \\
\text { inti Centre for Ecoliteracy }\end{array}$ & Indikator Keberhasilan Penelitian \\
\hline $\begin{array}{l}\text { Aspek } \\
\text { pengetahuan }\end{array}$ & 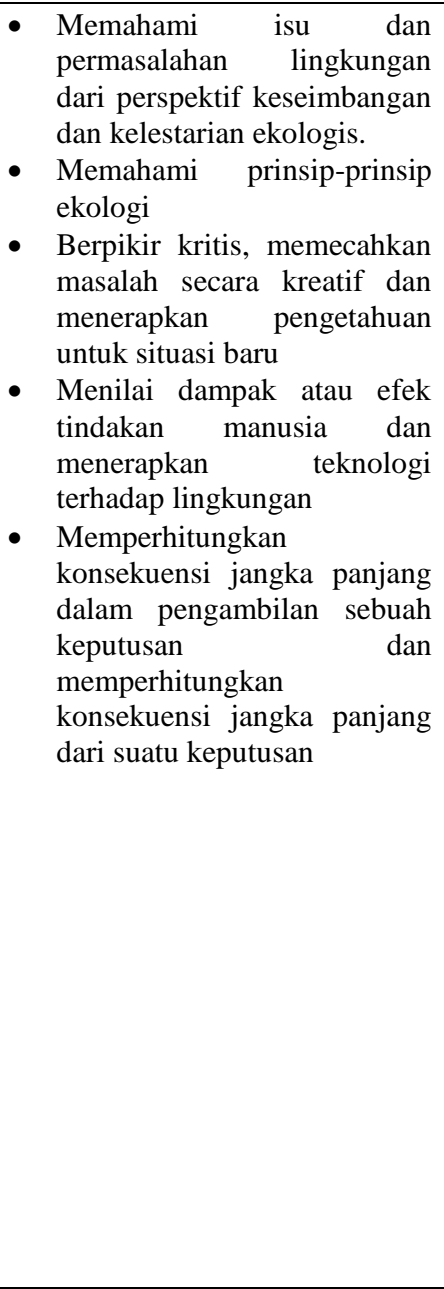 & $\begin{array}{l}\text { - Peserta didik mendeskripsikan kaitan antara } \\
\text { pola permukiman penduduk dengan jenis } \\
\text { transportasi yang digunakan. } \\
\text { - Peserta didik dapat menyusun skala prioritas } \\
\text { dalam memilih jenis transportasi hemat BBM } \\
\text { yang digunakan ke sekolah. } \\
\text { - Peserta didik dapat menjelaskan kegiatan } \\
\text { ekonomi produksi, konsumsi dan distribusi } \\
\text { BBM. } \\
\text { - Peserta didik dapat memahami dan } \\
\text { menunjukkan perilaku kecerdasan ekologis } \\
\text { terhadap lingkungan hidup sekitarnya dalam } \\
\text { kehidupan sehari-hari dikaitkan dengan } \\
\text { pengggunaan BBM. } \\
\text { - Peserta didik mendeskripsikan kelangkaan } \\
\text { BBM yang meliputi faktor penyebab, } \\
\text { dampak dan solusinya dalam kehidupan } \\
\text { sehari-hari. } \\
\text { - Peserta didik dapat mendeskripsikan manfaat } \\
\text { bersepeda sebagai solusi mengatasi } \\
\text { kelangkaan BBM. } \\
\text { - Peserta didik dapat menganalisa dampak } \\
\text { kegiatan bersepeda terhadap keadaan } \\
\text { lingkungan. } \\
\text { - Peserta didik dapat mendeskripsikan manfaat } \\
\text { bersepeda dari berbagai aspek. } \\
\text { Peserta didik dapat menganalisa penggunaan } \\
\text { sepeda motor oleh para pelajar sebagai } \\
\text { kegiatan konsumsi. } \\
\text { Peserta didik dapat memahami bahaya } \\
\text { penggunaan sepeda motor bagi anak di } \\
\text { bawah umur. } \\
\text { Peserta didik mendeskripsikan tindakan } \\
\text { kreatif dalam menghias sepeda untuk } \\
\text { keperluan karnaval. }\end{array}$ \\
\hline Aspek sikap & 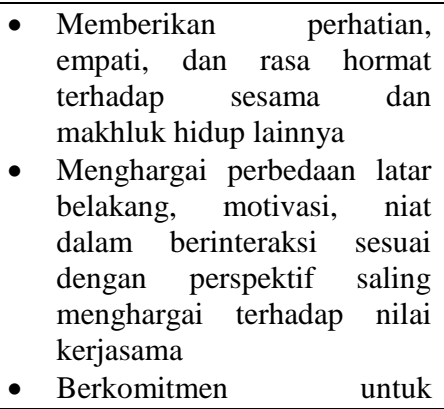 & $\begin{array}{l}\text { - Peserta didik memiliki kesadaran menghemat } \\
\text { BBM. } \\
\text { - Peserta didik meyakini melalui bersepeda } \\
\text { menjadi salah satu upaya menjaga keadaan } \\
\text { ekologi. } \\
\text { - Peserta didik memiliki ikatan yang kuat } \\
\text { dengan alam dengan ikut andil dalam } \\
\text { menghemat BBM dengan bersepeda } \\
\text { kesekolah. } \\
\text { - Peserta didik bisa membuat pilihan berjalan } \\
\text { kaki/bersepeda dibandingkan dengan }\end{array}$ \\
\hline
\end{tabular}




\begin{tabular}{|c|c|c|}
\hline $\begin{array}{c}\text { Kompetensi inti } \\
\text { dari Centre for } \\
\text { Ecoliteracy }\end{array}$ & $\begin{array}{l}\text { Subkompetensi dari kompetinsi } \\
\text { inti Centre for Ecoliteracy }\end{array}$ & Indikator Keberhasilan Penelitian \\
\hline & $\begin{array}{lr}\text { kesamaan, } & \text { keadilan, } \\
\text { inklusivitas, } & \text { dan } \\
\text { menghormati semua orang }\end{array}$ & $\begin{array}{l}\text { menggunakan sepeda motor bagi yang } \\
\text { tinggal berdekatan dengan sekolah. } \\
\text { - Peserta didik berkomitmen untuk tidak } \\
\text { mengendarai sendiri sepeda motor sebagai } \\
\text { alat transportasi ke sekolah. } \\
\text { - Peserta didik menunjukkan sikap untuk mau } \\
\text { berjalan kaki atau bersepeda ke sekolah. }\end{array}$ \\
\hline $\begin{array}{l}\text { Aspek } \\
\text { keterampilan }\end{array}$ & $\begin{array}{l}\text { - } \text { Membuat dan menggunakan } \\
\text { alat-alat, benda, dan produser } \\
\text { yang dibutuhkan oleh } \\
\text { masyarakat } \\
\text { berkelanjutan } \\
\text { - Menerapkan dalam tindakan } \\
\text { praktis dan efektif dalam } \\
\text { menerapkan pemahaman } \\
\text { yang peduli terhadap } \\
\text { keseimbangan ekologis } \\
\text { - Menilai dan memanfaatkan } \\
\text { energi dan sumber daya } \\
\text { sesuai kegunaannya }\end{array}$ & $\begin{array}{l}\text { - Peserta didik sudah merencanakan untuk } \\
\text { memakai sepeda menggantikan sepeda motor } \\
\text { yang digunakan ke sekolah. } \\
\text { - Peserta didik mempersiapkan sepeda yang } \\
\text { akan digunakan ke sekolah. } \\
\text { - Peserta didik mempraktekkan berjalan } \\
\text { kaki/bersepeda ke sekolah. } \\
\text { - Peserta didik merasakan langsung manfaat } \\
\text { kegiatan bersepeda. } \\
\text { - Peserta didik dapat mensosialisasikan } \\
\text { dampak penggunaan BBM bagi lingkungan. } \\
\text { - Peserta didik mengkomunikasikan manfaat } \\
\text { bertransportasi hemat BBM kepada } \\
\text { temannya dari kelas lain. } \\
\text { Peserta didik mengajak temannya untuk } \\
\text { berjalan kaki/bersepeda ke sekolah } \\
\text { Peserta didik dapat mensosialisasikan } \\
\text { dampak penggunaan BBM bagi lingkungan. } \\
\text { Peserta didik mampu merancang kegiatan } \\
\text { karnaval sepeda. } \\
\text { Peserta didik dapat berkreasi menghias } \\
\text { sepedanya dengan sepeda yang dimilikinya } \\
\text { untuk kepentingan karnaval. } \\
\text { Peserta didik sudah bersepeda ke sekolah. }\end{array}$ \\
\hline
\end{tabular}

Diadaptasi dari Centre for Ecoliteracy (2004).

Berdasarkan pedoman indikator yang dikembangkan pada tabel di atas, kemudian diintegrasikan dengan SK 6 Memahami kegiatan ekonomi masyarakat yang terdiri dari KD 6.1, 6.2, 6.3, dan 6.4 dalam Kurikulum KTSP 2006 mata pelajaran IPS kelas VII semeseter genap dan diharapkan dapat mengukur peningkatan kecerdasan ekologis peserta didik dalam bertransportasi hemat BBM melalui pembelajaran IPS kontesktual pada materi kelangkaan sumber daya alam.

\section{B. Transportasi Hemat BBM}

Transportasi hemat BBM disebut juga dengan green transportation atau transportasi hijau. Menurut Andriyani dan Yuliastuti (2003), transportasi hijau merupakan sarana transportasi dengan dampak yang rendah pada lingkungan, termasuk transportasi non-motorized yaitu berjalan kaki dan bersepeda, penggunaan kendaraan hijau, casharing, serta berusaha untuk membangun atau melindungi sistem trasportasi yang hemat bahan bakar dan ruang sehingga dapat menciptakan gaya hidup yang sehat. Transportasi hijau merupakan transportasi yang sedikit atau tidak menghasilkan gas rumah kaca.

Organisasi untuk kerjasama dan pembangunan ekonomi (OECD) dalam Noviyanti (2014) menyebut transportasi hijau sebagai transportasi berkelanjutan. Transportasi berkelanjutan merupakan suatu transportasi yang tidak menimbulkan dampak yang membahayakan kesehatan masyarakat atau ekosistem dan dapat 
memenuhi kebutuhan mobilitas yang ada secara konsisten dengan memperhatikan: a) penggunaan sumberdaya terbarukan pada tingkat yang lebih rendah dari tingkat regenerasinya; dan b) penggunaan sumber daya tidak terbarukan pada tingkat yang lebih rendah dari pengembangan sumberdaya alternatif yang terbarukan.

Penelitian ini mengkhususkan kepada sepeda sebagai transportasi hemat BBM. Sepeda dikatakan sebagai transportasi hemat BBM, karena dalam pengoperasiannya tidak menggunakan BBM sehingga dapat menghemat ketersediaan bahan bakar minyak. Melalui penelitian ini peneliti mengharapkan peserta didik yang sebelumnya memiliki sepeda tetapi belum dimanfaatkan secara optimal dan lebih memilih menggunakan sepeda motornya ke sekolah dapat difungsikan kembali pengunaannya, sedangkan peserta didik yang lain yang sudah menerapkan perilaku hemat BBM dapat semakin kuat komitmennya untuk tetap menghemat BBM dan tidak menggunakan sepeda motor ke sekolah.

Manfaat bersepeda diungkapkan oleh Ainsley (2009, hlm. 53) bahwa "Old, young, tourer, commuter or mountain biker, whatever your age or favourate from cycling, getting on a bike just as good for your mental health as it is for your physical health'. Bersepeda, berapa pun usianya, baik tua maupun muda sangat bermanfaat untuk kesehatan fisik maupun kesehatan mental. Secara lebih rinci, manfaat bersepeda juga dikemukakan oleh komunitas bike to work (dalam Affari, 2011) bahwa:

Bersepeda baik untuk kesehatan dan mengurangi waktu yang harus kita sisihkan untuk berolahraga secara khusus, membantu mengurangi konsumsi $\mathrm{BBM}$, mengurangi pengeluaran harian kita untuk mobile, dan bebas polusi, baik itu polusi udara yang dikeluarkan knalpot kendaraan bermotor maupun polusi suara yang diakibatkan oleh pembakaran bahan bakar fosil yang bisa membuat planet biru kita ini semakin panas, mungkin ini adalah langkah kecil, tapi kami bangga untuk mengatakan bahwa kami telah dan terus berusaha untuk mengurangi kontribusi CO2 kami di jalan. (hlm. 6)

Hasil penelitian Sirard dan Slater (2016) tentang "Walking and Bicycling to School"; menunjukkan bahwa berjalan dan bersepeda ke sekolah setiap hari merupakan strategi yang dapat meningkatkan aktivitas fisik dan menurunkan berat badan. Pendapat ini bisa dimungkinkan karena dengan berjalan dan bersepeda setiap hari, maka otot-otot tubuh aktif bergerak dan dapat meningkatkan metabolisme tubuh semakin lancar.

\section{Pembelajaran IPS Kontekstual}

1. Pembelajaran IPS

IPS merupakan mata pelajaran yang diajarkan di tingkat SD/MI dan SMP/MTs. Hal ini sebagaimana dikemukakan oleh Somantri (2001, hlm. 74) bahwa "Pendidikan IPS adalah suatu penyederhanaan disiplin ilmu-ilmu sosial, ideologi negara dan disiplin ilmu lainnya serta masalah-masalah sosial terkait, yang diorganisasikan dan disajikan secara ilmiah dan psikologis untuk tujuan pendidikan pada tingkat pendidikan dasar dan menengah".

Selaras dengan pendapat tersebut, NCSS (dalam Somantri, 2001. hlm 10) mengemukakan bahwa:

Social studies is the integrated study of the social sciences and humanities to promote civic competence... The primary purpose of social studies is to help young people develop the ability to make informed and reasoned decision for 
the public good as citizens of culturally diverse, democratic society in an independent world.

Definisi tersebut mengandung makna bahwa IPS sebagai sebuah kajian yang sumbernya berasal dari ilmu-ilmu sosial dan humaniora memiliki peran yang sangat penting dalam mewujudkan warga negara yang baik dimana tujuannya adalah mempersiapkan generasi muda untuk memiliki kemampuan untuk membuat keputusan yang rasional yang akan diterapkan dalam kehidupan bermasyarakat. Warga negara yang baik tentunya adalah warga negara yang mampu mengelola hubungan dengan lingkungan sekitarnya dengan baik.

Adapun tujuan pendidikan IPS yang dikembangkan Departemen Pendidikan Nasional (dalam Sapriya, 2015, hlm. 201) sebagai berikut:

1. Mengenal konsep-konsep yang berkaitan dengan kehidupan masyarakat dan lingkungannya.

2. Memiliki kemampuan dasar untuk berpikir logis dankritis, rasa ingin tahu, inkuiri, memecahkan masalah, dan keterampilan dalam kehidupan sosial

3. Memiliki komitmen dan kesadaran terhadap nilai-nilai sosial dan kemanusiaan.

4. Memiliki kemampuan berkomunikasi, bekerja sama dan berkompetisi dalam masyarakat yang majemuk, di tingkat lokal, nasional, dan global.

Dari beberapa penjelasan di atas, maka dapat disimpulkan tujuan utama yang ingin dicapai dalam pembelajaran IPS, yakni mengarahkan peserta didik menjadi warga negara yang baik yang memiliki kompentensi aspek pengetahuan, sikap, dan keterampilan untuk memecahkan persoalan-persoalan sosial yang dialami peserta didik dalam kehidupan nyata yang semakin mengglobal.

\section{Pembelajaran Kontekstual (CTL)}

Pembelajaran kontekstual merupakan model pembelajaran yang berupaya mengaitkan materi yang dipelajari dengan situasi nyata peserta didik dan mendorong peserta didik untuk membuat hubungan antara pengetahuan yang dimilikinya dengan menerapkannya dalam kehidupan mereka sehari-hari sebagai individu, anggota masyarakat dan bangsa (Sanjaya, 2011; Daryanto dan Raharjo, 2012; dan Poedjiadi, 2005).

Pembelajaran kontekstual menurut Ditjen Dikdasmen (dalam Sanjaya, 2011, memiliki tujuh komponen utama yaitu konstruktivisme (constructivism), menemukan (inquiry), bertanya (questioning), masyarakat belajar (learning community), pemodelan (modelling), refleksi (reflection), dan penilaian yang sebenarnya (authentic assessment). Adapun ketujuh komponen tersebut dapat dijelaskan sebagai berikut:

1. Konstruktivisme (constructivism)

Dalam pembelajaran kontekstual, peserta didik berperan aktif dalam membangun pengetahuannya sendiri berdasarkan pengalaman baru sebagai pengetahuan awalnya. Peserta didik bukan hanya menerima pengetahuan dari guru, melainkan mencari, menggali dan menyusun pengetahuannya sendiri.

2. Menemukan (inquiry)

Dalam pembelajaran kontekstual, peserta didik belajar bukan hanya hasil dari mengingat fakta-fakta, akan tetapi melalui hasil menemukan melalui proses berpikir secara sistematis. 
3. Bertanya (questioning)

Peserta didik didorong untuk berani bertanya, mengemukakan pendapat, ide-ide atau gagasannya dan menjawab pertanyaan-pertanyaan yang diajukan oleh guru.

4. Masyarakat belajar (Learning Community)

Hasil belajar didapatkan dengan bekerjasama dengan orang lain melalui kegiatan kelompok-kelompok belajar.

5. Pemodelan (modelling)

Pembelajaran ditampilkan dengan memperagakan sesuatu sebagai contoh yang dapat ditiru oleh setiap peserta didik. Model tersebut bisa oleh guru ataupun "ahli" yang kompeten dibidangnya, bahkan peserta didik itu sendiri bisa dijadikan model. Model tersebut didatangkan ke dalam kelas atau juga sebaliknya, peserta didik yang mengunjungi model tersebut.

6. Refleksi (reflection)

Cara berpikir tentang apa yang telah dipelajari atau berpikir ke belakang tentang apa-apa yang sudah dilakukan di masa lalu, kemudian mengendapkannya sebagai pengetahuan baru yang merupakan revisi dari pengetahuan sebelumnya. Refleksi ini dilakukan terhadap kejadian, aktivitas, atau pengetahuan yang baru diterima.

7. Penilaian sebenarnya (authentic assessment)

Merupakan proses yang dilakukan oleh guru untuk mengumpulkan informasi tentang perkembangan belajar peserta didik. Kemajuan belajar dilakukan dengan berbagai cara, antara lain melalui penilaian tertulis (pencil and paper test), penilaian berdasarkan perbuatan (performance based assessment), penugasan (project), produk (product) atau portofolio (portofolio). Hal ini dimaksudkan supaya penilaian bersifat menyeluruh dan menggambarkan kemampuan peserta didik sesungguhnya.

Menurut Bern dan Erickson (dalam Komalasari, 2014, hlm. 55-56) model pembelajaran kontekstual dapat diterapkan dengan menggunakan strategi dan metode yang bervariasi.

Sumber belajar dalam pembelajaran kontekstual dapat berupa sumber materi bacaan (buku teks, LKS, ensiklopedia, buku referensi, internet, majalah, dan kliping) dan materi bukan bacaan (gambar-gambar, foto, ilustrasi, film strips, film atau video, rekaman, grafik, kartun, poster, papan buletin, karyawisata, museum, laboratorium dan pajangan, perpustakaan dan lingkungan sekitar sekolah, serta masyarakat dengan mengundang anggota atau tokoh masyarakat setempat ke dalam kelas untuk berbicara dengan peserta didik atau mengunjungi langsung anggota atau tokoh masyarakat tersebut di tempat mereka tinggal atau bekerja). Sumber belajar yang ada di lingkungan peserta didik dapat berupa masyarakat desa atau kota di sekeliling, lingkungan fisik sekitar sekolah, bahan sisa, sampah atau limbah tak terpakai, dan peristiwa yang terjadi di masyarakat (Jarolimek dalam Komalasari, 2014, hlm. 116143).

Deskripsi langkah-langkah dalam pembelajaran kontekstual menurut Daryanto \& Rahardjo (2012, hlm. 156) terdiri dari:

1. Kembangkan pemikiran bahwa anak akan belajar lebih bermakna dengan cara bekerja sendiri, dan mengkonstruksi sendiri pengetahuan dan keterampilan barunya.

2. Laksanakan sejauh mungkin kegiatan inquiri untuk semua topik.

3. Kembangkan sifat ingin tahu siswa dengan bertanya. 
4. Ciptakan masyarakat belajar.

5. Hadirkan model sebagai contoh pembelajaran.

6. Lakukan refleksi di akhir pertemuan.

7. Lakukan penilaian yang sebenarnya dengan berbagai cara.

Menurut Komalasari (2014, hlm. 248-249), kekuatan pembelajaran kontekstual antara lain:

1. Pembelajaran kontekstual memungkinkan siswa belajar dengan baik, karena apa yang dipelajari terkait dengan apa yang telah diketahui dan dengan kegiatan atau peristiwa yang terjadi di sekelilingnnya.

2. Pembelajaran kontekstual membelajarkan prinsip saling ketergantungan, diferensiasi, dan memiliki hak mengatur diri.

3. Pembelajaran kontekstual mendukung penciptaan pembelajaran demokrasi dalam rangka mengembangkan siswa menjadi warga negara yang cerdas, demokratis, bertanggungjawab, dan partisipatif.

4. Pembelajaran kontekstual mengembangkan kesadaran diri (self-awareness) melalui penerapan konsep assessmen autentik. Melalui asesmen ini siswa dilatih kesadaran dan penghargaan terhadap kemampuan diri, kesediaan menerima kritik yang konstrukrif, dan keberanian memberikan kritik yang sopan.

\section{Kelangkaan Sumber Daya Alam}

Kelangkaan (scarcity) merupakan salah satu konsep utama dalam ekonomi. Menurut Ahmadi dan Amri (2011, hlm. 108), kelangkaan merupakan suatu kondisi dimana terdapat ketidakseimbangan antara kebutuhan manusia yang tidak terbatas dengan alat pemuas kebutuhan yang jumlahnya terbatas. Pendapat lain dikemukakan oleh Supardan (2013) yang mengemukakan bahwa;

...skarsitas atau kelangkaan adalah sebuah prinsip bahwa sebagian besar barang yang diinginkan orang hanya tersedia dalam jumlah yang terbatas, kecuali barang bebas seperti udara. Dengan demikian, barang pada umumnya dalam keadaan langka dan harus dijatah, baik melalui mekanisme harga maupun cara lainnya. (hlm. 398)

Penyebab utama timbulnya kelangkaan adalah (1) tekanan jumlah penduduk, (2) perbedaan akses terhadap sumber daya, (3) persaingan maupun konflik materialistik (Supardan, 2014, hlm. 400).

Fauzi (2004, hlm. 4) mengemukakan sumber daya alam sebagai sumber daya hayati dan non-hayati yang dimanfaatkan oleh manusia sebagai sumber pangan, bahan baku dan energi. Secara umum, sumber daya ini dapat diklasifikasikan ke dalam sumber daya yang dapat diperbaharui (flow/reneweble) dan sumber daya alam yang tidak diperbaharui (stok/nonreneweble). Sumber daya alam yang dapat diperbaharui merupakan sumber daya alam yang dapat diregenerasi. Contohnya tumbuh-tumbuhan dan hewan, sedangkan sumber daya alam yang tidak dapat diperbaharui merupakan sumber daya alam yang ketersediaannya terbatas. Contohnya sumber daya mineral, logam, minyak dan gas bumi. Sumber daya alam yang dimaksud dalam penelitian ini dibatasi dalam bentuk bahan bakar minyak (BBM) yang dipakai sepeda motor, yaitu bensin.

Kelangkaan sumber daya alam dalam penelitian ini dimaksudkan sebagai suatu keadaan dimana adanya ketidakseimbangan antara kebutuhan manusia akan BBM yang tidak terbatas dengan alat pemuas kebutuhan (BBM) yang terbatas. BBM 
yang dimaksud adalah bensin sebagai bahan bakar sepeda motor yang digunakan oleh peserta didik.

\section{METODE PENELITIAN}

Penelitian ini menggunakan pendekatan kualitatif dengan metode penelitian tindakan kelas (PTK) atau Classroom Action Research. PTK merupakan metode penelitian tentang bagaimana sekelompok guru dapat mengorganisasikan kondisi praktek pembelajaran mereka dan belajar dari pengalaman mereka sendiri. Dalam penelitian ini, guru dapat mencobakan suatu gagasan perbaikan dalam praktek pembelajaran dan melihat pengaruh nyata dari upaya yang dilakukan tersebut (Wiriaatmadja, 2014, hlm. 13). Penelitian tindakan kelas ini bertujuan untuk meningkatkan kompetensi kecerdasan ekologis peserta didik dalam bertransportasi hemat BBM sekaligus mengimplementasikan kompetensi tersebut dalam kehidupan sehari-hari peserta didik melalui pembelajaran IPS Kontekstual.

Model PTK yang digunakan adalah model PTK Elliot. Berdasarkan model Elliot, penelitian ini diawali dengan langkah identifikasi masalah dan memeriksa masalah (reconnasissance) sebelum tahap perencanaan, pelaksanaan, observasi, dan refleksi pada siklus I, sedangkan siklus II dan III diawali revisi rencana awal, perencanaan, pelaksanaan, observasi dan refleksi. Adapun gambaran mengenai model PTK Elliot dapat dilihat dari gambar 1 berikut ini:

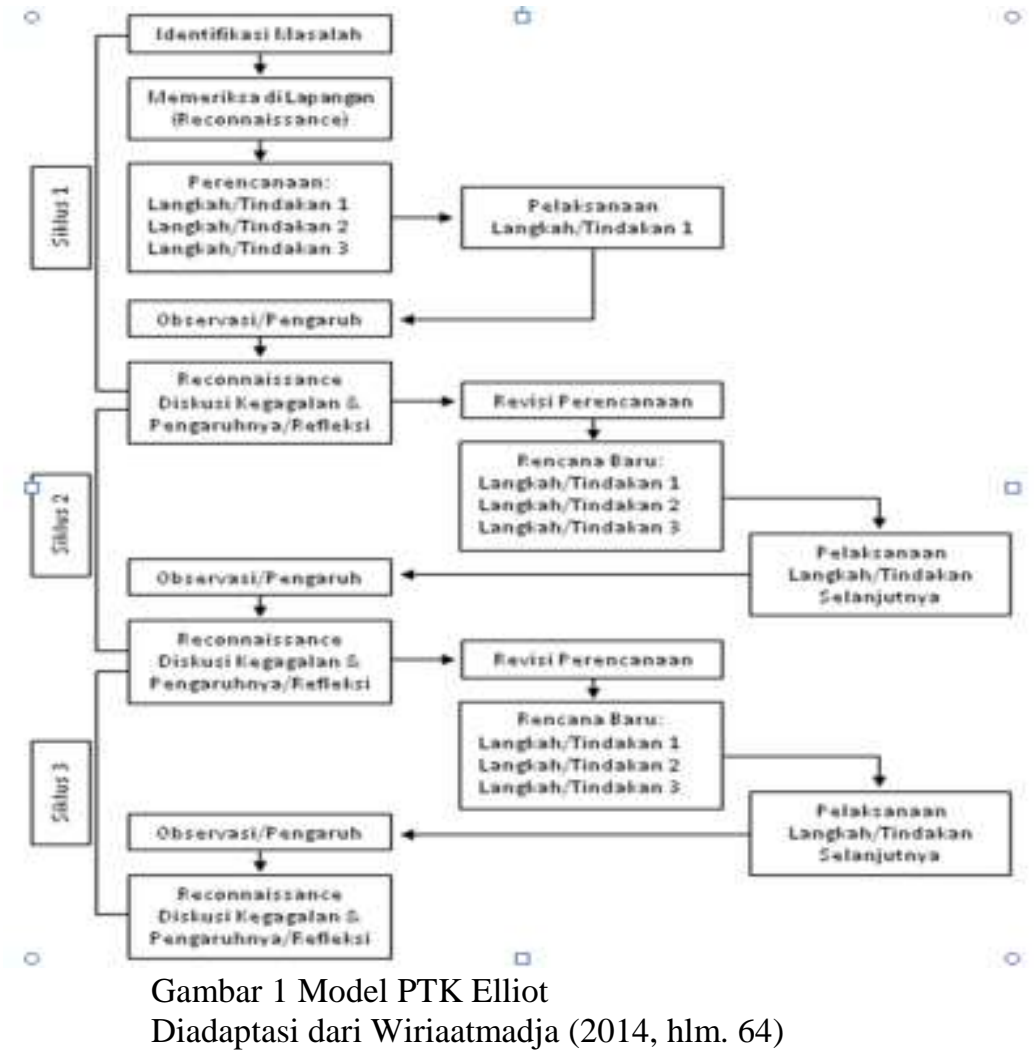

Partisipan atau subyek penelitian tindakan kelas ini adalah peserta didik kelas VII A SMP Negeri 2 Tomo Kabupaten Sumedang yang berjumlah 25 orang terdiri dari 13 orang perempuan dan 12 orang laki-laki. Waktu pelaksanaan penelitian ini berlangsung kurang lebih selama 5 bulan terhitung mulai bulan Januari 2016 sampai Mei 2016. Penelitian ini direncanakan tiga siklus dengan beberapa kali pertemuan 
sesuai dengan kebutuhan. Pembelajaran kontekstual dilakukan di dalam maupun di dengan startegi dan model yang beragam. Lama waktu tindakan penelitian ditentukan oleh keberhasilan dalam mencapai indikator keberhasilan penelitian.

Teknik pengumpulan data yang digunakan dalam penelitian ini adalah observasi, tes, dokumentasi, wawancara, jurnal kesan dan lembar kerja siswa. Instrumen penilaian yang digunakan untuk mengukur peningkatan aspek pengetahuan adalah tes uraian dan hasil diskusi LKS. Peningkatan aspek sikap berdasarkan data yang diperoleh dari hasil observasi, wawancara, dokumentasi, penilaian diri dan jurnal kesan, sedangkan untuk mengukur peningkatan aspek keterampilan menggunakan observasi, penilaian proyek, penilaian diri dan dokumentasi. Data yang diperlukan untuk diambil dan diolah oleh peneliti yaitu data yang berhubungan dengan aktivitas peserta didik dan guru selama proses pembelajaran berlangsung dan upaya peningkatan kecerdasan ekologis dalam bertransportasi hemat BBM melalui pembelajaran IPS kontekstual.

Analisis data menggunakan analisis data dari Miles dan Huberman yang terdiri dari tiga alur kegiatan yang terjadi secara bersamaan yaitu reduksi data, penyajian data dan penarikan kesimpulan atau verifikasi.

\section{HASIL PENELITIAN}

Penelitian tindakan kelas ini dilaksanakan berpedoman kepada Rencana Pelaksanaan Pembelajaran (RPP) yang telah disusun oleh peneliti dengan guru mitra. Melalui pembelajaran IPS Kontekstual, diharapkan adanya peningkatan kecerdasan ekologis peserta didik dalam bertransportasi hemat BBM, baik aspek pengetahuan, sikap maupun keterampilan yang pada akhirnya diaplikasikan dalam kehidupan sehari-hari peserta didik.

Siklus I dilaksanakan sebanyak empat tindakan yang difokuskan untuk membangun kecerdasan ekologis aspek pengetahuan peserta didik dalam upaya menemukan dan memahami isu-isu lingkungan yang ada di sekitar kehidupan mereka sehari-hari, yaitu mengenai kelangkaan BBM dan dampaknya terhadap kehidupan serta bahaya penggunaan sepeda motor bagi pelajar SMP. Meskipun fokus utamanya adalah membangun pengetahuan, akan tetapi aspek sikap dan keterampilan pun mulai dipupuk dan dikembangkan sehingga dalam setiap siklus diharapkan akan nampak peningkatannya. Strategi yang digunakan adalah Two Stay Two Stray pada tindakan pertama. Dengan strategi ini peserta didik dapat menggali informasi tentang jenis transportasi yang digunakan teman-temannya ke sekolah beserta alasan penggunaan moda transportasi tersebut melalui investigasi yang dilakukan antar kelompok. Pada tindakan kedua, pembelajaran dengan menggunakan pemodelan dari narasumber petugas pom bensin mini. Dengan metode ini peserta didik mempunyai keberanian dalam bertanya dan mengkonstruksi pengetahuannya tentang kegiatan ekonomi produksi, konsumsi, dan distribusi BBM. Tindakan ketiga dan keempat pembelajaran disajikan dengan strategi decision trees (pohon masalah) yaitu dengan membuat pohon masalah dalam kelompoknya dengan tujuan agar peserta didik dapat memahami dan mengeksplorasi pengetahuannya tentang isu-isu lingkungan seperti kelangkaan BBM dan penggunaan sepeda motor oleh para pelajar mulai dari akar permasalahan (penyebab), dahan (dampaknya), dan ranting (solusi masalah) yang kemudian hasilnya dipresentasikan di depan kelas oleh perwakilan masing-masing kelompok. Mereka pada akhirnya sepakat untuk memilih alternatif solusi bertransportasi hemat BBM untuk diterapkan dalam kehidupan sehari-hari sebagai 
upaya mengantisipasi kelangkaan BBM dan dampaknya serta mengurangi maraknya penggunaan sepeda motor diantara mereka.

Siklus II dilaksanakan dalam empat tindakan berdasarkan hasil refleksi dan evaluasi siklus I. Kelemahan pada siklus I diperbaiki pada siklus II. Peneliti dan guru mitra menyusun RPP berdasarkan hasil refleksi. Pada siklus II pembelajaran diarahkan untuk menumbuhkan dan menanamkan kesadaran peserta didik mengenai pentingnya bertransportasi hemat BBM dan bahaya penggunaan sepeda motor di kalangan pelajar melalui pemodelan dari narasumber guru IPS, guru olahraga, dan anggota polisi lalu lintas sektor Tomo yang dihadirkan ke dalam kelas. Sikap peserta didik dalam bertransportasi ke sekolah mulai berubah, terutama setelah bertanya jawab dan pemaparan yang diberikan oleh narasumber anggota polsek Tomo tentang etika berlalu lintas. Mereka semakin menyadari bahaya yang ditimbulkan akibat menggunakan sepeda motor dan mulai menggunakan sepedanya menggantikan sepeda motor yang biasa mereka gunakan. Selain itu, peserta didik yang sebelumnya berjalan kaki ke sekolah komitmennya semakin kuat untuk tidak bersepeda motor ke sekolah. Adapun peserta didik yang tetap menggunakan angkutan umum beralasan letak rumahnya jauh dari sekolah dan tidak mempunyai sepeda.

Siklus III dilaksanakan dalam empat tindakan berdasarkan hasil refleksi dan evaluasi siklus II. Aspek keterampilan merupakan fokus utama pencapaian kecerdasan ekologis pada siklus ini. Siklus ini merupakan implementasi dari siklus I dan siklus II. Melalui metode demonstrasi bertransportasi hemat BBM (bersepeda) dan merancang serta melaksanakan kegiatan karnaval sepeda hias dengan bahanbahan yang mudah ditemukan dalam kehidupan sehari-hari peserta didik, pengetahuan mereka mengenai pentingnya bertransportasi hemat BBM dan dampak penggunaannya serta etika bersepeda semakin meningkat. Begitu pula dengan sikap mereka yang menunjukkan sikap tidak malu ataupun gengsi bersepeda ke sekolah. Mereka juga nampak mengajak teman-temannya dari kelas lain untuk bersepeda ke sekolah. Dengan demonstrasi bersepeda, peserta didik dapat merasakan manfaat bersepeda secara langsung. Kreativitas dalam merancang dan melaksanakan karnaval sepeda hias nampak dengan hasil proyek yang mencerminkan beragamnya ide-ide dalam menghias sepedanya.

\section{KESIMPULAN}

Desain pembelajaran IPS Kontekstual dimulai dengan penyusunan silabus yang merupakan pengintegrasian antara Kurikulum 2006 dengan indikator kompetensi kecerdasan ekologis yang diadaptasi dari Center for Ecoliteracy. Kemudian menyusun RPP sesuai dengan SK/KD dalam silabus dengan pemilihan materi yang dapat dipadukan dengan pengembangan peningkatan kompetensi kecerdasan ekologis peserta didik sesuai dengan kebutuhan.

Implementasi atau pelaksanaan pembelajaran IPS kontekstual melalui strategi dan metode yang bervariasi untuk meningkatkan kecerdasan ekologis peserta didik bertransportasi hemat BBM secara umum berjalan dengan lancar, bahkan peserta didik sangat antusias dalam setiap pertemuan. Respon mereka sangat positif, apalagi ketika belajar di luar kelas, yaitu ketika praktek bersepeda dan karnaval sepeda hias. Selain itu, melalui pemodelan dengan tayangan video dan menghadirkan guru olahraga dan anggota polisi lalu lintas semakin menguatkan kesadaran peserta didik untuk mengurangi ketergantungan terhadap penggunaan transportasi berbahan bakar fosil dan beralih menggunakan transportasi hemat BBM. 
Hasil refleksi antara peneliti dengan guru mitra terhadap pelaksanaan setiap siklus digunakan sebagai pedoman untuk memperbaiki kendala dan hambatan yang dihadapi dalam siklus sebelumnya. Siklus berikutnya sudah dilakukan perbaikan sehingga pelaksanaan pembelajaran semakin berjalan sesuai dengan rencana.

Setelah dilakukan serangkaian perlakuan dan tindakan dari mulai siklus I sampai siklus III melalui pembelajaran IPS Kontekstual menunjukkan adanya peningkatan kompetensi kecerdasan ekologis peserta didik dari berbagai aspek, baik pengetahuan, sikap, maupun keterampilan dari tiap siklusnya. Rata-rata peningkatan kecerdasan ekologis setiap siklus berada di kategori "kurang" pada siklus kesatu, kategori "cukup" pada siklus kedua, dan kategori "baik" pada siklus ketiga. Peningkatan aspek pengetahuan lebih tinggi dari pada aspek sikap dan keterampilan. Hal ini menunjukkan perlunya kesinambungan dalam peningkatan kecerdasan ekologis peserta didik dalam bertransportasi hemat BBM, terutama dalam pencapaian aspek sikap dan keterampilan. Peneliti menyadari untuk mengubah mind set peserta didik memang tidak mudah dan memerlukan waktu. Akan tetapi, dengan adanya perubahan sikap mereka yang semakin menyadari pentingnya menjaga lingkungan dengan mengurangi ketergantungan terhadap penggunaan transportasi berbahan fosil sudah merupakan perubahan yang cukup berarti. Berdasarkan gambaran di atas, maka dapat dikatakan bahwa pembelajaran IPS kontekstual efektif meningkatkan kecerdasan ekologis peserta didik dalam bertransportasi hemat BBM dan dapat diterapkan di sekolah pertama lainnya yang memiliki karakteristik daerah yang serupa. Selain itu, peneliti merekomendasikan agar pihak-pihak terkait seperti kepala sekolah, komite sekolah, guru, orang tua dan masyarakat lebih dimunculkan lagi peranannya dalam penelitian selanjutnya.

\section{DAFTAR PUSTAKA}

Affari, L. (2011). Dampak aktivitas bersepeda terhadap kesehatan mental emosional: Studi kasus pada komunitas pekerja bersepeda bike to work Bandung. (Tesis), Sekolah Pascasarjana, Universitas Pendidikan Indonesia, Bandung.

Ahmadi, I. K.A. \& Amri, S. (2011). Mengembangkan pembelajaran IPS Terpadu. Analisis kritis tentang metode, strategi, evaluasi dan media pembelajaran bidang studi sejarah, geografi, ekonomi, sosiologi, antropologi dan isu pembelajaran IPS Terpadu. Jakarta: PT Prestasi Pustakakarya.

Ainsley, R. (2009, Desember-Januari). Happy Cycling. Cycle. Hlm 52-53. Diakses dari www.ctc.org.uk/file/member/201001052pdf. Desember-januari 2010.

Andriyani, D. N. dan Yuliastuti, N. (2013). Penilaian Sistem Transportasi yang Mengarah Pada Green Transportasi di Kota Surakarta. Jurnal Pembangunan Wilayah dan Kota, 9 (2), hlm. 183-193.

Apandi, I. (2015). Pendidikan lalu lintas bagi pelajar. [Online]. Diakses dari http://www.kompasiana.com/idrisapandi/pendidikan-lalu-lintas-bagi pelajar 552e38236ea83474238b4589.

Ardiansyah, R. (2015). Peningkatan ecoliteracy peserta didik dalam sanitasi toilet sekolah melalui metode demonstrasi dalam pembelajaran IPS (Penelitian Tindakan Kelas di Kelas VII A SMPN 4 Situraja Kabupaten Sumedang Provinsi Jawa Barat). Pascasarjana, Universitas Indonesia, Bandung.

Center for Ecoliteracy. (2004). Ecoliteracy competencies. [Online]. Diakses dari http://www.ecoliteracy.org/publications/fritjop . 
Daryanto \& Rahardjo, M. (2012). Model pembelajaran inovatif. Malang: Penerbit Gava Media.

Depdiknas (2013). Pembelajaran Berbasis Kontekstual.

Fauzi, A. (2). Ekonomi sumber daya alam dan lingkungan: Teori dan aplikasi. Jakarta: PT Gramedia Pustaka Utama

Gardner, H. (2013). Multiple intelligences: Kecerdasan majemuk: Teori dalam praktek. (A. Sindoro, Trans). Batam: Interaksara.

Goleman, D. (2010). Ecological intelligence. Kecerdasan ekologis. Mengungkap rahasia di balik produk-produk yang kita beli. Jakarta: PT Gramedia Pustaka Utama.

Komalasari, K. (2014). Pembelajaran kontekstual konsep dan aplikasi. Bandung: PT Refika Aditama.

Noviyanti, E. (2014). Pengembangan infrastruktur yang hemat energi untuk mengurangi efek urban heat island di kawasan CBD kota Surabaya (UP. Tunjungan).

Palmer, J. A. (1998). Environtmental education in the 21st century. New York: Routledge.

Poedjiadi, A. (2005). Sains Teknologi Masyarakat: Model pembelajaran kontekstual bermuatan nilai. Bandung: PT Remaja Rosdakarya.

Rahadian, F. (2014). Kajian kriminologi tentang pelanggaran lalu lintas yang dilakukan oleh anak; Studi kasus di wilayah hukum Polrestabes Semarang. [Online]. Diakses dari hhtp://febryrahadian.blogspot.co.id/20014/07/kajiankriminologi-tentang-pelanggaran 21.html.

Sanjaya, W. (2011). Strategi pembelajaran berorientasi standar proses pendidikan. Jakarta: Kencana Prenada Media.

Somantri, M. N. (2001). Menggagas pembaharuan Pendidikan IPS. Bandung: Penerbit Rosdakarya.

Supardan, D. (2013). Pengantar Ilmu Sosial: Sebuah kajian pendekatan struktural. Jakarta: PT Bumi Aksara.

Supriatna, N. (2016). Ecopedagogy: Membangun kecerdasan ekologis dalam Pembelajaran IPS. Bandung: Penerbit PT Remaja Rosdakarya.

Wiriaatmadja, R. (2009). Metode penelitian tindakan kelas untuk meningkatkan kinerja guru dan dosen. Bandung: Program Pascasarjana UPI dengan PT Remaja Rosdakarya. 